\title{
STUDY OF LOCAL GOVERNMENT PROBLEMS IN IMPLEMENTATION OF DEVELOPMENT BUDGET POLICY PLANNING IN ECONOMIC SECTOR OF INDONESIA
}

\author{
Silalahi Engelbertha E. ${ }^{*}$, Aba Fransiskus X Lara, Lydia Ni Luh Gde \\ Faculty of Economics and Business, Atma Jaya Catholic University, Indonesia \\ ${ }^{*}$ E-mail: engelberthasilalahi1972@gmail.com
}

\begin{abstract}
Purpose of this study is to provide recommendations for development budget planning in leading sectors of the economy. Preparation of policy planning of Regional Revenue and Expenditure Budget by using this performance-based budget system prioritizes efforts to achieve the allocation of output work plan and input costs. The projection shows, GRDP in Jakarta of Indonesia increased from Indonesia Rupiah (IDR) 543.02 trillion in 2016 to IDR. 565.42 trillion in 2017. Furthermore GRDP numbers continue to increase and reach the figure of IDR 659.32 trillion in 2021. Similarly, regional expenditure, the projection also shows that in 2017 regional expenditure has decreased to IDR 39.37 trillion (18.07\%) of regional revenue in 2016 amounting to IDR. 48.06 trillion.
\end{abstract}

\section{KEY WORDS}

Budget, policy, development, planning, local government, economic sector.

The study of the implementation of economic development budget policy can not be separated from the impact of planning that must be seen as an integral part in every process both in making and implementation of the decision. As a consequence, the policy of planning will be meaningless unless decentralization is followed in its implementation (Conyers et al, 1990). According to Austen and Banks, (1988) Decentralization itself is the responsibility for the planning and or alternative implementation of the balance of power between the central and regional governments in formulating the economic development budget policy on what which will be faced for development in the present and future. In other words, the implementation of a decentralized development budget planning policy is a political process that needs to be further analyzed.

Implementation of local financial policies should be harmoniously in support of development programs to achieve substantial regional economic growth (Aba, Yussof, Saidatulakmal.; 2015). Government revenue and expenditure budgets need to be laid out in a budget system capable of improving governance both in general governmental duties and development tasks (Foremny, et al, 2014). Some of the causes that make the budget in Jakarta Indonesia hampered, the result of the delay is caused by (1). The organizational stability is not conducive for the Regional Device Work Unit (RDWU) to show good performance. Even RDWU, tend to be very careful to make a breakthrough through a program. (2). Government steps in Jakarta Indonesia using e-budgeting as a budgeting system is also still immature. This makes RDW difficult to apply. (3). To be imposed ebudgeting, ultimately accessing the opening of game gaps in auctions made via e-budgeting (Schofield and Sened., 2006).

Routine and development budget in Jakarta Indonesia needs to be more synchronized and consolidated according to budget planning that is continuous, gradual and increasing with maximum orientation of the results. Based on the above point of view, the problem of local government in absorbing Regional Budget of Jakarta is still very low. Based on reports from the regional finance and asset management board, the absorption of the budget only reached 13.86 percent or IDR. 8.03 trillion from the total IDR.67.1 trillion. The lack of budget absorption is considered to have implications for the low cost of infrastructure development for communities in Jakarta Indonesia. In that context, Jakarta Indonesia still needs a high cost to build an adequate public infrastructure. Moreover, people need the realization of the 
maximum budget to finance development in Jakarta Indonesia. This provides a role in the economic base of income as well as the position of each economic activity for the Regional Revenue and Expenditure Budget (RREB) in the absorption of the budget for the acceleration of economic improvement and public services in Jakarta Indonesia (Bararuallo, and Aba., 2017).

\section{METHODS OF RESEARCH}

Analysis of Structure and Growth of RREB (Adiab, et al., 2007) is the RREB Structure analyzed by looking at the contribution of revenue sources and expenditure items relative to total RREB in Jakarta Indonesia. According to Baltagi, (2001), revenue growth and expenditure in RREB for eight years (1993-2000) will be calculated using the exponential trend equation (Holt, 1957), and projection analysis from 2017 - 2021. Analysis of RREB Capacity (Albacete, and Lindner, 2013), is to look at the performance of local government revenues and expenditures of Jakarta Indonesia using the ratio of revenue to GRDP and revenue to development budget (Gomes, 2015).

\section{RESULT OF STUDY}

Based on Hunter Blair (2016), the budget is the estimated performance to be achieved over a given period of time expressed in financial size. the budget can be defined as a financial plan in the form of expenditures and sources of income for one year. There is a close relationship between budget, planning and control (Arian and Shamir, 2011). Planning is used to see what action should be taken to achieve a particular goal in the future (Blekesaune .; 2007), while control is more looking backward, determining what actually happened and comparing it with planning.

Meanwhile, according to Binzer and Klemmemsen (2005), the budget is a document showing the condition or financial condition of an organization that provides information on income (Alesina and Tabellini, 2007), expenditures, activities and objectives to be achieved. Revenue and Expenditure Budget (RREB) is the state budget prepared every year. Therefore, the RREB has a very important role because it becomes one of the main tools for the welfare of the community.

Budgeting is a process or method for preparing a budget (Miekatrien Sterck and Bram Scheers, 2006). Budgeting is a process of translating an activity plan into a financial plan (Weimer and Vining, 2005). In a broader sense, budgeting involves budget preparation, implementation, control, and accountability known as the budget cycle. Budgeting is related to the process of determining the amount of fund allocations for programs and activities. So, it can be concluded that the budget is the driving force and budgeting is the process to prepare the budget.

One of the instruments that can be used to analyze the financial capacity of the region is the instrument of GRDP (BPS.; 2017). The instrument provides an indication of the potential and dominant role of the regional economic sector seen from the creation of output and added value as well as final demand (Kuhlmann, 1998). Ratio of RREB to GRDP is to see how far the role of local government in providing public services through government expenditure in RREB (Aba., 2017).

Table 1 - Ratio of Regional Revenue and Expenditure Budget / RREB to GRDP in Jakarta Indonesia, 1992-1997

\begin{tabular}{|cccc|}
\hline Years & RREB (Million IDR) & GRDP (Million IDR) & Ratio (\%) \\
\hline 1992 & $1,130,731.3$ & $16,001,557.0$ & 7.1 \\
1993 & $1,476,521.3$ & $51,106,389.0$ & 3.3 \\
1994 & $1,847,936.7$ & $55,505,268.0$ & 4.0 \\
1995 & $2,404,720.8$ & $60,638,216.0$ & 4.3 \\
1996 & $2,835,833.8$ & $66,164,802.0$ & 4.3 \\
1997 & $2,981,385.6$ & $69,543,347.0$ & \\
\hline
\end{tabular}

Source: Data Analyzed by Researcher. 
The expenditure ratio on GRDP performance in Jakarta Indonesia showed a declining trend in 1993 (2.9\%), then increased annually from 1994 (3.3\%) to $1997(4.3 \%)$. Means, the ability of local governments in providing public services is getting better. The proportion of expenditure in the Revenue and Expenditure Budget is an indicator to see the effectiveness of government expenditures on increasing output generated in the regional economy. In other words, the ratio of Revenue and Expenditure Budget to the increasing GRDP shows that the proper allocation of expenditure budget can spur economic development in Jakarta Indonesia.

The expenditure ratios on GRDP performance in Jakarta Indonesia showed a downward trend in 1998 (3.1\%), then increased in 1999 (6.0\%), then decreased annually from $2000(5.2 \%)$ to $2002(3,5 \%)$. This means, the ability of local governments in providing public services has not improved. The proportion of expenditure in the Revenue and Expenditure Budget is an indicator to see the effectiveness of government expenditures on increasing output generated in the regional economy. In other words, the ratio of Revenue and Expenditure Budget to the decreasing GRDP indicates that the expenditure budget has not been appropriately allocated in order to spur economic development in Jakarta Indonesia. More can be seen in the table below.

Table 2 - Ratio of Regional Revenue and Expenditure Budget / RREB to GRDP in Jakarta Indonesia, 1997-2002

\begin{tabular}{|cccc|}
\hline Years & RREB (Million IDR) & GRDP (Million IDR) & Ratio (\%) \\
\hline 1997 & $2,981,385.6$ & $69,543,347.0$ & 4.3 \\
1998 & $1,802,068.9$ & $57,380,517.0$ & 3.1 \\
1999 & $3,434,601.1$ & $57,215,224.0$ & 6.0 \\
2000 & $3,127,364.2$ & $59,694,418.0$ & 5.2 \\
2001 & $9,274,825.6$ & $238,656,139.0$ & 3.9 \\
2002 & $8,754,245.8$ & $250,331,157.0$ & 3.5 \\
\hline
\end{tabular}

Source: Data Analyzed by Researcher.

The expenditure ratio on GRDP performance in Jakarta Indonesia shows an increasing trend every year from $2003(3.9 \%)$ to $2007(5.2 \%)$. This means, the ability of local governments in providing public services is improving.

Table 3 - Ratio of Regional Revenue and Expenditure Budget / RREB to GRDP in Jakarta Indonesia, 2002-2007

\begin{tabular}{|cccc|}
\hline Years & RREB (Million IDR) & GRDP (Million IDR) & Ratio (\%) \\
\hline 2002 & $8,754,245.8$ & $250,331,157.0$ & 3.5 \\
2003 & $10,382,597.1$ & $263,624,242.0$ & 3.9 \\
2004 & $11,493,273.3$ & $278,524,823.0$ & 4.1 \\
2005 & $12,435,352.4$ & $295,270,545.0$ & 4.2 \\
2006 & $15,161,577.7$ & $312,751,711.0$ & 4.8 \\
2007 & $17,280,823.4$ & $332,971,255.0$ & 5.2 \\
\hline
\end{tabular}

Source: Data Analyzed by Researcher.

The proportion of expenditure in the Revenue and Expenditure Budget is an indicator to see the effectiveness of government expenditures on increasing output generated in the regional economy. In other words, the ratio of Revenue and Expenditure Budget to the increasing GRDP indicates that the proper allocation of expenditure budget can spur economic development in Jakarta Indonesia.

Ratio of expenditure on GRDP performance in Jakarta showed a declining trend in $2008(4.5 \%)$, then increasing every year from 2009 (5,3\%) until 2012 (7.0\%). This means, the ability of local governments in providing public services is improving.

The proportion of expenditure in the Revenue and Expenditure Budget is an indicator to see the effectiveness of government spending on increasing output generated in the regional economy. In other words, the ratio of Revenue and Expenditure Budget to the 
increasing GRDP shows that the proper allocation of expenditure budget has been able to spur economic development in Jakarta Indonesia.

Table 4 - Ratio of Regional Revenue and Expenditure Budget / RREB to GRDP in Jakarta Indonesia, 2007-2012

\begin{tabular}{|cccc|}
\hline Years & RREB (Million IDR) & GRDP (Million IDR) & Ratio (\%) \\
\hline 2007 & $17,280,823.4$ & $332,971,255.0$ & 5.2 \\
2008 & $15,956,526.1$ & $353,723,390.0$ & 4.5 \\
2009 & $19,511,099.4$ & $371,469,500.0$ & 5.3 \\
2010 & $21,555,447.7$ & $395,633,574.0$ & 5.4 \\
2011 & $26,423,682.2$ & $422,121,511.0$ & 6.3 \\
2012 & $31,558,706.9$ & $449,805,475.0$ & 7.0 \\
\hline
\end{tabular}

Source: Data Analyzed by Researcher.

The expenditure ratio on GRDP performance in Jakarta Indonesia shows an increasing trend in $2013(8.0 \%)$, then declines in 2014 (7.5\%), and further increases again in 2015 $(8.2 \%)$ through $2016(8.9 \%)$. This means, the ability of local governments in providing public services is improving. The proportion of expenditure in the Revenue and Expenditure Budget is an indicator to see the effectiveness of government expenditures on increasing output generated in the regional economy. In other words, the ratio of Revenue and Expenditure Budget to the increasing GRDP shows that the proper allocation of expenditure budget has been able to spur economic development in Jakarta Indonesia.

Table 5 - Ratio of Regional Revenue and Expenditure Budget / RREB to GRDP in Jakarta Indonesia, 2012-2016

\begin{tabular}{|cccc|}
\hline Years & RREB (Million IDR) & GRDP (Million IDR) & Ratio (\%) \\
\hline 2012 & $31,558,706.9$ & $449,805,475.0$ & 7.0 \\
2013 & $38,294,384.9$ & $477,285,245.0$ & 7.0 \\
2014 & $37,759,773.0$ & $504,225,592.0$ & 8.2 \\
2015 & $43,031,322.9$ & $523,925,770.0$ & 8.9 \\
2016 & $48,059,574.8$ & $543,020,428.0$ & \\
\hline
\end{tabular}

Source: Data Analyzed by Researcher.

The budgeting system in Indonesia is reflected in the State Budget. According to Goyal Ashima (2010), the state budget is the government's annual financial plan approved by the House of Representatives, which contains a systematic list and details of state revenue and expenditure plans for one fiscal year (1 January-31 December) act and implemented openly and responsibly to maximize people's prosperity.

The consists of state revenues and grants, state expenditures, and financing. State Budget is the main instrument of fiscal policy to direct the national economy and stimulate economic growth. The amount of budget absorption will have an impact on the higher rate of economic growth. The ratio of realized expenditure absorption of Ministries or Institutions to budget realization is a form of indicator of effectiveness of state expenditure. In addition, State Badget policy is expected to respond to the dynamics of the people both related to broad economic development, as well as the life of the people themselves, so that required a flexible fiscal policy.

To see the picture of the economy in Jakarta Indonesia in the future can be done by projecting the amounts obtained in the structure of GRDP. Projection Results GRDP in Jakarta Indonesia 5 years (2017 - 2021) increased from IDR. 543.02 trillion in 2016 to IDR. 565.42 trillion in 2017. Furthermore GRDP numbers continue to increase and reach the figure of IDR. 659.32 trillion in 2021.

The analysis results show the result of projection of regional and government expenditure in Jakarta Indonesia in 2017 - 2021. Projection data indicate that in 2017 local revenue decreased to IDR. 41.40 trillions (12.91\%) from the previous year's revenue of IDR. 47.54 trillion. Regional income figures then increase every year to reach IDR. 49.07 trillion in 2021. 
Similarly, regional spending, the projection also shows that in 2017 regional expenditure has decreased to IDR. 39.37 trillion (18.07\%) of the previous year's revenues of IDR. 48.06 trillion. Regional expenditure subsequently increase every year to reach IDR. 46.71 trillion by the year 2021 .

\section{DISCUSSION OF RESULTS}

Regional economic development efforts face various opposition from within and outside (Bargsted and Kedar., 2009). This situation requires the ability and policy of Jakarta Indonesia government to make the process of accelerating the preparation and implementation of economic development that focus on economic base. The results of the study indicate that the use of development budget in Jakarta Indonesia relies too much on development costs to non-RREB funds. Local government in Jakarta Indonesia has financed development with Corporate Social Responsibility (CSR) funds. Such a breakthrough is even contradictory to the RREB that has been approved because it makes him abandoned and not absorbed maximally. So far, programs conducted using non-budget funds such as CSR, to note, to date there are indeed some infrastructure in Jakarta Indonesia built using CSR funds such as Lenggang Jakarta, the location built for street vendors Monas area. In addition, there is also the procurement of garbage trucks, Integrated Child Friendly Public Space Development, procurement bus city tour level, handling Pluit dam and Rio Ria.

Comparative study of the implementation of economic development budget (Armstrong, and Taylor (2000) in collecting data and information on the state of the region and the potential of the economic sectors it possesses as input determination in clarifying the regional economic picture objectively, thus providing the necessary input in determination of local government policy (Rosenthal, 2012) for the creation of innovative economic development systems (Conyers and Hills, 1990).

\section{CONCLUSION}

Based on budget implementation as part of policy implementation, it can be assumed that budget implementation is influenced by interests that focus on political power and decisions. The outcomes of economic development and policy implementation by the Regional Government in Jakarta Indonesia can ultimately be evaluated and assessed for success through the economic measures of budget use that have been achieved according to plan, it is seen through the government's accountability report, , objective community reports as well as reports from the results of scientific research conducted by the community or social institutions that demonstrate the performance of the implementation of regional development.

From the discovery shows the trend of budget use for 25 years showed fluctuations in the absorption. This is seen also at the end of the year projection results show, GDP in Jakarta Indonesia increased from IDR. 543.02 trillion in 2016 to IDR. 565.42 trillion in 2017. Furthermore GRDP numbers continue to increase and reach the figure of IDR. 659.32 trillion in 2021. Similarly, regional expenditure, the projection also shows that in 2017 regional expenditure has decreased to IDR. 39.37 trillion (18.07\%) of regional revenue in 2016 amounting to IDR. 48.06 trillion. These performance results continue to be used as inputs for subsequent policy evaluations in revising some errors in the policy to be reassembled into future policy planning guidelines.

\section{REFERENCES}

1. Aba, F.X.L. 2015, 'Analysis of Economic Structure in Poverty Eradication in the Province Of East Nusa Tenggara Indonesia', ELSEVIER, Journal Procedia - Social and Behavioral Sciences Volume 211, 25 November 2015, Pages 81-88

2. Aba, F. X. L. 201). Effect Of Income, Population, Government Spending, Export Goods And Services Of Regional Economic Sector In Indonesia. In Economic And Social 
Development (Book Of Proceedings), 19th International Scientific Conference On Economic And Social (P. 27).

3. Adiab, A., Leigh, D., Mody, A., 2007. International Finance and Income Convergence: Europe is Different. IMF Working Paper.

4. Albacete, N. and P. Lindner. 2013. Household Vulnerability in Austria - A Microeconomic Analysis Based on the Household Finance and Consumption Survey. In: OeNB. Financial Stability Report 25. 57-73.

5. Alesina, A. and Tabellini, G., 2007, Bureaucrats or politicians? Part I: A single policy task. American Economic Review, 97(1), pp. 169-179.

6. Arian, A. and Shamir, M., 2011, Introduction, in: A. Arian and M. Shamir (Eds.) The Elections in Israel 2009 (Piscataway, NJ: Transaction Publishers).

7. Austen-Smith, D. and Banks, J. S., 1988, Elections, coalitions and legislative outcomes. American Political Science Review, 82(2), pp. 405-422.

8. Armstrong, H.W. and J. Taylor. 2000. Regional Economics and Policy, Oxford: Blackwell.

9. Badan Pusat Statistik (BPS). (2017). DKI Jakarta Dalam Angka / Jakarta Indonesia in Figures

10. Baltagi, B.H., 2001, Econometric Analysis of Panel Data (Chichester: John Weileyand Sons).

11. Bararuallo, and Aba, F.X.L., 2017. Influence Factors Determinants Absolute Poverty; Case Study in Indonesia. Global Journal of Business and Social Sciences Review 69-75.

12. Bargsted, M. and Kedar, O., 2009, Coalition-targeted Duvergerian voting: How expectations affect voter choice under proportional representation. American Journal of Political Science, 53(2), pp. 307-323.

13. Binzer Hobolt, S. 2005, Responsive government? Public opinion and government policy preferences in Britain and Denmark. Political Studies, 53, pp. 379-402.

14. Blekesaune, M., 2007, Economic conditions and public attitudes to welfare policies. European Sociological Review, 23(3), pp. 393403.

15. Conyers and Hills. 1990. An introduction to Development Planning in the Third Word. Brisbane Toronto Singapore.

16. Foremny, D., Freier, R., Moessinger, M.-D., Yeter, M., 2014. Overlapping political budget cycles in the legislative and the executive. DIW Discussion Paper 1429.

17. Gomes, O., 2015. A budget setting problem. In: Dynamics, Games and Science International Conference and Advanced School Planet Earth, DGS II. Springer International Publishing, pp. 285-294 (chapter 15).

18. Goyal, Ashima. 2010, "Budgetary Processes: A Political Economy Perspective", MPRA Paper No 27786, Munich.

19. Greiner, A., 2011. Economic growth, public debt and welfare: comparing three budgetary rules. German Economic Review 12, 205-222

20. Holt, C.C. 1957. Forecasting Seasonals and Trends by Exponentially Weighted Moving Averages. ONR Research Memorandum 52, Carnegie Institute of Technology, Pittsburgh, Pennsylvania.

21. Kuhlmann, S. 1998 Moderation of policy making? Science and technology policy evaluation beyond impact measurement - the case of Germany, Evaluation, 4(2), pp. 130-148.

22. MyJoy Online, 2014. Blame Political Leaders for Slums - Town \& Planning Expert. Ghanaweb Regional News, Tuesday 08, July.

23. Miekatrien Sterck \& Bram Scheers. 2006. Trends in Performance Budgeting in Seven OECD countries, Public Performance \& Management Review, 30:1, 47-72

24. Rosenthal, M., 2012, Agenda control in an unstable parliamentary democracy: Evidence from the Israeli Public sector. Constitutional Political Economy, 23(1), pp. 22-44.

25. Schofield, N. J. and Sened, I., 2006, Multiparty Democracy (New York: Cambridge University Press). Sened, I., 1995, Equilibria in weighted voting games with side payments. Journal of Theoretical Politics, 7, pp. 283-300.

26. Weimer, D. L. and Vining, A., 2005, Policy Analysis: Concepts and Practices (Upper Saddle River, NJ: Prentice Hall). 